\title{
THE REQUIREMENT OF DELIVERY AS APPLIED TO GIFTS OF CHOSES IN ACTION
}

\author{
PaUL W. BrutoN
}

Both the doctrine of delivery and the law of gifts of choses in action have been the subjects of a great deal of learned investigation and discussion. The theoretical interest and practical importance 2 of the legal problems covered by these topics have induced such extended treatment that it may seem to be going over old material to renew the discussion here. But it appears to the writer that there is one corner of the field which has received comparatively little attention, but which merits careful consideration. This belief is justified by a reference to a section of the Restatement of Contracts published by the American Law Institute. In dealing with the subject of gratuitous assignments, the framers of that laudable work state the law as follows:

"The right acquired by the assignee under a gratuitous assignment is revocable by the assignor's death, by a subsequent assignment by the assignor, or by notice from the assignor received by the assignee or by obligor, unless: (a) the assignment is in a writing either under seal or of such a nature as to be capable of transferring title to a chattel without delivery thereof and without consideration; or (b) the assigned right is evidenced by a tangible token or writing, the surrender of which is required by the obligor's contract for its enforcement and this token or writing is delivered to the assignee; or (c) the assignor should reasonably expect the assignment to induce action or

'See Ames, Inalienability of Choses in Action (1909) 3 Selecr Essuxs IN ANGLO-AMIERICAN LEgaL HISTORY 580; Cook, The Alicnability of Choses in Action (1916) 29 HARv. L. Rev. 816; Cook, The Alicnability of Choses in Action: A reply to Professor Williston (1917) 30 Harv. L. REv. 449; Costigan, Gifts Inter Vivos of Choses in Action (1911) 27 L. Q. REv. 326; Jenks, Consideration and the Assignment of Choses in Action (1900) 16 L. Q. Rev. 241; Williston, Is the Right of an Assignee of a Chose in Action Legal or Equitable? (1916) 30 HARv. L. REv. 97. For a reply to the article by Professor Jenks see, Anson, Assignment of Choses in Action (1901) 17 L. Q. Rev. 90.

For a discussion of delivery see MIechem, The Rcquirement of Delivery in Gifts of Chattels and Choses in Action Evidenced by Commcreial Instruments" (1926) 21 ILL. L. REv. 341, 457, 568; Stone, Delivery in Gifts of Personal Property (1920) 20 CoL. L. Rev. 196; Pollock, Gifts of Chattels Without Delivery (1890) 6 L. Q. REv. 446.

2 As to the importance of the law of gifts, one of the writers on the subject makes the following statement: "A very brief examination of the authorities is sufficient to convince one that recent years have witnessed a large increase, both in the number of litigated gifts, and in the value of the property involved." Mechem, op. cit. supra note 1, at 311, n. 5. 
forbearance of a definite and substantial character on the 'part of the assignee and such action or forbearance is induced." 3

Particular attention is called to Subsection (b), which raises the problem to be discussed in this paper.4

What is meant by a "tangible token or writing, the surrender of which is required by the obligor's contract for its enforcement," is made clearer by the comment appended to the Restatement. Commenting on Subsection (b) the authors state:

"Surrender of a tangible token or writing is required by the obligor's contract not only where the requirement is stated in express terms, but also where it is a proper implication from business usage or other surrounding circumstances." s

The following illustration is then given:

"A delivers gratuitously to $B$ a memorandum and a written contract, in each case evidence of an obligation of $C$ to $A$, but of which the surrender is not required by the respective contracts as a condition of enforcing a right against $C$, with the expressed intent of making $B$ the owner of the rights of which these documents are evidence. A's death, a subsequent assignment by him or a notice delivered by him to $\mathrm{B}$ or $\mathrm{C}$ revokes the gift, and if $\mathrm{B}$ thereafter obtains satisfaction of the obligation he must sur. render the proceeds to $A$ or to his estate or his subsequent assignee." 6

From this discussion it is clear that, so far as ordinary simple contracts are concerned, the kind of instrument the authors are referring to is one which, by the express or implied terms of the assigned contract, is required to be presented or surrendered to the obligor as a condition of the obligor's duty to perform, and they do not propose to include within their definition of "deliverable" instruments documents which are purely evidentiary in character and which are essential to the enforcement of the con-

3 CoNTracts Restatement (Am. L. Inst. 1928) c. 1-7, § 158.

4 This paper does not deal with gifts by way of written assignment or order. As to gift by check, of. Rolls v. Pearce, 5 Ch. D. 730 (1877); In re Swinburne, [1926] Ch. 38.

5 Contracts Restatement (Am. L. Inst. 1928) c. 1-7, § 158.

- The authors admit that the case of In re Huggins' Estate, $204 \mathrm{~Pa}$. 167, 53 Atl. 746 (1902) presented this exact situation and the court held the assignment irrevocable. They evidently contend that the caso was wrongly decided. Contracts RESTATEMENT (Am. L. Inst. 1928) 271. For further discussion of this case, see infra at 856 .

7 The framers of the Restatement admit that an obligation evidenced by a non-negotiable bond, a life insurance policy, or a certificate of stock may be irrevocably assigned by the delivery of the document. Contracts RESTATEMENT (Am. L. Inst. 1928) c. 1-7, p. 192, illustration 1. Just how these instruments differ from the ordinary written contract is not made clear. 
tract only in so far as they are necessary evidence of its terms. ${ }^{8}$ It is respectfully submitted that such an interpretation of the law of assignment is not sustained by the authorities and that a review of the cases will show that an irrevocable gratuitous assignment may be created by the delivery of an instrument acknowledging the indebtedness or obligation on the part of the obligor to the assignor and which, in any action for the enforcement of the assigned contract, would be the best evidence of the obligee's claim, even though the instrument is not required to be presented to the obligor as a condition of enforcing the contract against him. It is the purpose of the present paper to show the basis of this contention by reviewing the development of the doctrine of delivery as applied to gifts of choses in action.

It is well known that by the early law a chose in action was unassignable ${ }^{3}$ and that the doctrine of delivery was first worked out with reference to the transfer of tangible chattels. The origin of the idea that without written assignment property can be transferred only by delivery has been the subject of considerable speculation. There seems to be good ground for believing that it developed from the notion in the early law that seisin was an element in the ownership of chattels as well as of land. ${ }^{20}$ It most certainly had its origin in part in the medieval point of view of the early judges who failea to realize clearly the distinction between tangible things and intangible rights in things. To the matter-of-fact judge of the middle ages the obvious way to transfer a thing was to hand it over; and to permit $A$ to say that

8 The only cases cited by the framers of the Restatement as supporting their interpretation of the law are those relating to gifts of bank deposits. Contracts Restatenient (Am. L. Inst. 1928) c. 1-7, pp. 270-271. These are cases holding that the delivery of a bank pass-book is insufficient to create an irrevocable assignment for the reason that such a book is not required to be presented at the bank when withdrawals are made. Such cases are the only ones cited as supporting the rule of the Restalcment; but it is submitted that they do not stand for the broad proposition that the delivery of an instrument completely evidencing a chose cannot create an irrevocable assignment unless the instrument delivered is one required to be presented to the obligor as a condition of enforcing the contract against him. This question is discussed below.

${ }^{9}$ It was the contention of Dean Ames that choses in action never did become completely alienable and that an assignee, even in the modern law, received merely a power of attorney. See Ames, op. cit. supra, note 1, at 580 . For further discussion of Dean Ames' theory see Cook, articles op. cit. supra note 1; Williston, op. cit. supra note 1. Practically no trace of this "Power of Attorney" theory is found in the Restatcment by the American Law Institute.

But even Dean Ames admitted that the delivery of a document representing the chose, such as a common law or mercantile specialty, created an irrevocable assignment. See Costigan, op. cit. supra note 1.

10 See Maitland, The Seisin of Chattels (1885) 1 L. Q. REv. 324; Ames, The Disseisin of Chattels (1889) 3 HARV. L. REv. 23, 313, 337. 
he gave a horse to $B$ while at the same time keeping possession of it was too contradictory to be considered.11 However this may be, it was firmly established before choses in action became assignable ${ }^{12}$ that an irrevocable gift of personal property could be made only by written assignment properly executed, or by delivery of the res. ${ }^{13}$

It is extremely difficult to regulate the transfer of property on a strictly possessory basis and, therefore, as the significance of seisin as an element of transfer by gift faded into the past and as judges began more fully to realize the nature of property and property rights, a tendency appeared to accept other evidence, equally corroborative of the intent to give, in lieu of actual transfer of possession.14 This tendency to qualify the requirement of actual delivery of possession first appeared in the theory of constructive delivery. The delivery of a key to a chest would substitute for the actual delivery of the property in the chest, ${ }^{13}$ for this was a transfer of the means of acquiring possession of the property given.

Thus the stage was set when, in the early part of the eighteenth century, the sudden influx of cases dealing with gifts causa mortis ${ }^{16}$ presented new problems to test the old rules. In 1744 in the case of Snellgrove v. Baily, ${ }^{17}$ Lord Hardwicke gave the first discussion of the doctrine of delivery as applied to choses in action. That was the case of a gift causa mortis of a bond which had been delivered by the donor to the donee. The chancellor held the gift valid saying, "You cannot sue at lnw without a bond; for though you may give evidence of a deed at law that is lost, yet you cannot of a bond, because you must

11 See Mechem, op. cit. supra note 1 , where the cases dealing with delivery are exhaustively reviewed and a rational basis for the theory is suggested.

12 The earliest case holding that a chose in action may be assigned by delivery of a written instrument is Jones v. Selby, Prec. Ch. 300 (1710), where it was held that Exchequer Tallies were proper subjects of a gift causa mortis.

13 The two leading English cases standing for this proposition are Irons v. Smallpiece, 2 B. \& Ald. 551 (1819) and Cochrane v. Moore, 25 Q. B. D. 57 (1890).

is A case forcibly illustrating this tendency is Hillebrant v. Brewer, 6 Tex. 45 (1851), where the court held that the registration of a cattlo brand by a father in the name of his child and the branding of cattlo in the possession of the father with the intention of giving them to the child was a good gift of the cattle to the child. The delivery was symbolical or constructive.

15 Lucas v. Lucas, 1 Atk. 270 (1738).

10 This influx was evidently due to a desire to assist legatees whoso gifts failed to comply with the Statutes of Frauds recently passed. Seo Rundell, Gifts of Choses in Action (1918) 27 Yare L. J. 643.

173 Atk. 214 (1744). 
make profert of it." ${ }^{18}$ Having held that a good gift causa mortis of a bond could be made by delivery, the court was soon asked to apply its ruling to another kind of instrument. Eight years later in the famous case of Ward v. Turncr, ${ }^{20}$ Lord Hardwicke was presented with the question of how far the new law permitting the assignment of choses in action would qualify the old rules of delivery. The case was similar on its facts to many which have come before the courts in recent years. The donor, having possession of certain receipts for South Sea Annuities which were owned by him, but which were in the custody of a third party, transferred the receipts to the donee with the expressed intent of making a gift causa mortis. It was argued for the validity of the gift that "where livery cannot be, the best evidence that nature will admit, being only to show the mind of the donor, will do," but the court held the gift incomplete. In speaking of Snellgrove v. Baily, ${ }^{\prime 0}$ Lord Hardwicke said:

"It was argued that there was no want of actual delivery there or possession, the bond being but a chose in action, and therefore there was no delivery but of the paper. If I went too far in that case, it is not a reason I should go farther: and I chuse to stop there. But I am of the opinion that decree was right, and differs from this case; for though it is true that a bond, which is specialty, is a chose in action, and its principal value consists in the thing in action, yet some property is conveyed by the delivery; for the property is vested; and to this degree that the law-books say, the person to whom this specialty is given, may cancel, burn, and destroy it; the consequence of which is, that it puts it in his power to destroy the obligee's power of bringing an action, because no one can bring an action on a bond without a profert in cur." 21

In discussing constructive delivery, the Lord Chancellor continues:

". . . delivery of the key of bulky goods, where wines, etc., are, has been allowed as delivery of the possession, because it is the way of coming at the possession, or to make use of the thing: and therefore the key is not a symbol, which would not do. If so, then the delivery of these receipts amounts to so much waste paper; for if one purchases stock or annuities, what avail are they after acceptance of the stock? It is true, they are of some avail as to the identity of the person coming to receive: but after that is over, they are nothing but waste paper, and are seldom taken care of afterwards." 22

18 Ibid. 214. The Lord Chancellor was here referring to the rule of profert discussed below.

192 Ves. Sen. 431 (1752).

20 Supra note 17.

"I Supra note 19, at 442.

22 Ibid. 443. 
The reasoning of the case can be fully understood only by considering it in the light of the law as it then existed. By the rule of profert, mentioned in the decision, it was required, when suit was brought upon a sealed instrument, that the instrument itself should be presented in court as part of the pleadings. ${ }^{23}$ Profert was not excused if the instrument was lost or could not be procured, for the equitable doctrine permitting the proof of lost documents had not yet been fully recognized by the law courts. ${ }^{24}$ Under these rules of law it was not difficult to draw the analogy between the delivery of the bond and the delivery of the key. The former transferred control or "dominion" over the thing given quite as effectively as the latter. Transfer of the bond absolutely deprived the donor of the legal means of enforcing the chose represented by it.

Ward $v$. Turner ${ }^{25}$ formulated the doctrine which was the starting point for the law of delivery in gifts of choses in action. The case stands for two propositions which have been of tremendous importance in the development of the law. (1) It held that delivery, in the sense of transfer of control, was as necessary in gifts of choses in action as it was in gifts of tangible property. ${ }^{28}$ Proof of donative intent alone was as ineffectual in

${ }^{23}$ The rule of profert and its development into the so-called best evidenco rule is discussed in 2 WIGMORE, EVDDENCE (2d. ed. 1923) § 1177. See also Ames, Specialty Contracts and Equitable Defences (1895) 9 HARv. L. Rvv. 49.

24 When Lord Hardwicke made these technical rules the basis of his decision he undoubtedly did not foresee the changes in the law which woro soon to abolish the rule of profert which enabled him to distinguish between the delivery of a bond and the delivery of a receipt. Speaking of this in Duffield v. Elwes, 1 Bligh (N. S.) 497, 542 (1827), Lord Eldon said:

"Lord Hardwicke, with respect to the bond (and it is necessary that I should take some notice of this, because there has been a change in the law which that great judge did not foresee, but which, in later times, and in my own time, has become very familiar in the courts of law,) Lord Hardwicke states, as one ground of his opinion in the case of the bond, that it is a good gift causa mortis, because he says he who has got the bond may do what he pleases with it. He certainly disables the person who has not got the bond from bringing an action upon it: for, says Lord Hardwicke, no man ever heard-(and I have seen in the manuscript of the same Lord Hardwicke, that he said no man ever will hear) - that a person shall bring an action upon a bond without the profert of that bond; but we have now got into a practice of sliding from courts of equity into courts of law, the doctrine respecting lost instruments. ..." This quotation indicates very well the basis of Lord Hardwicke's decision and how it was undermined by subsequent changes in the law.

${ }^{25}$ Supra note 19.

28 This strict application of the doctrine of delivery to a gift of $a$ bond seems to show that Lord Hardwicke viewed the transaction as a completed transfer and not as an imperfect assignment which would be enforced in equity as a contract to assign. Since equity will not enforce a contract unsupported by consideration, it could not complete an imperfect voluntary 
one type of case as in the other. (2) Since the delivery required was transfer of control, the case determined the kind of a delivery which would satisfy this test as applied to a chose in action. Only the transfer of a document which would deprive the donor of the means of enforcing the chose would satisfy the test. For this purpose delivery of a specialty would do, but not the transfer of a simple writing, however strikingly that writing might evidence the chose. ${ }^{27}$ This was a very logical application of the previously developed law of delivery.

In a comparatively short time after this famous decision of Lord Hardwicke was rendered, the whole basis of it was swept away. Significant changes in the law took place. The rule of profert was supplanted by another rule of much broader but less stringent application. ${ }^{28}$ This later rule has continued down to the present time as the "best evidence" rule by which all writings are the best evidence of their own contents and they must be introduced to prove matters covered by their provisions unless they have been lost or destroyed, or their absence is otherwise satisfactorily accounted for. ${ }^{29}$ Under this changed state of the law, Lord Hardwicke's distinction between sealed and unsealed instruments has disappeared. The delivery of neither a specialty nor a simple writing any longer necessarily deprived the donor of the means of enforcing his chose, since they were essential only as a matter of proof and their contents could be shown by other evidence when their absence was satisfactorily accounted for. As a result of this situation, the courts were caught between two horns of a dilemma. They were compelled, either to reverse the holding in Ward $v$. Tumer ${ }^{30}$ and decide that gifts of choses could no longer be made by delivery of specialties, or to repudiate the theory of Ward $v$. Tumer and declare that delivery in the old sense of transfer of control was no longer necessary to sustain a gift of a chose in action. The English courts have ap-

assignment as a contract to assign. But a transfer of property does not require consideration to render it effective and, therefore, by treating the delivery of a bond as a transfer of the property represented by the bond, the transaction could be held effective, even though voluntary, without violating the principle that equity will not aid a volunteer.

${ }^{27}$ In Gardner v. Parker, 3 Madd. 184 (1818), where a bond was held a good subject of gift, the court said, "The case of Snellgrove v. Baily has established that there may be a donatio mortis causa of a bond, though not of a simple contract debt, nor by the delivery of a mere symbol." The use of the term "symbol" in the cases is fully as confusing as that of "dominion." It apparently connotes nothing more than a token, the transfer of which cannot create a valid and irrevocable gift.

28 The following cases may be referred to as showing the changes which resulted in the abolition of the rule of profert: Ex parte Greenway, 6 Ves. 812 (1802); Read v. Brookman, 3 T. R. 151 (1789).

292 WIGMORE, op. cit. supra note $23, \S 1177$.

so Supra note 19. 
parently followed the first course in dealing with gifts inter vivos and the second in determining the validity of gifts causa mortis.

The first case discussing gifts inter vivos of choses in action is $E d w a r d s v$. Jones, ${ }^{31}$ decided in 1836 . The facts were that $A$, owning certain bonds, endorsed a memorandum on them, purporting to be an assignment, and transferred them to $B$. $A$ died, and her executor, $X$, supposing the bonds to be lost, persuaded the obligor to give new bonds to cover the amount of the old ones. Upon the obligor's death, $X$ collected on the new bonds. $B$ then brought suit against $X$ to recover this money held by $X$. The court found that a gift inter vivos was intended and, therefore, that the transaction could not be held to be a gift causa mortis. The delivery of the bond did not complete the gift; and since the assignment was voluntary it could not be completed in equity. ${ }^{32}$ Why the delivery of a bond should be sufficient to complete a gift causa mortis but not a gift inter vivos is difficult to understand. The distinction may be explained by the greater leniency of the courts toward gifts causa mortis,, ${ }^{33}$ or perhaps by the fact that $E d w a r d s ~ v$. Jones ${ }^{34}$ was decided after the abolition of the rule of profert had rendered the reasoning of Ward $v$. Turner ${ }^{35}$ no longer applicable. Whatever the basis of the distinction, it has continued in the English law until the present time and the courts have generally followed Edwards v. Jones in holding that the delivery of a written instrument, even though a specialty, will not complete a gift inter vivos. ${ }^{30}$

\footnotetext{
811 Myl. \& C. 226 (1836).

32 This was nothing more than an application of the theory explained supra note 26.

ss Why the courts might be more lenient in such cases can be easily understood. When a gift causa mortis is litigated the donor is dead and he no longer has the opportunity of completing the gift if it is held defective; and if it is invalid the property passes to parties who obviously were not intended to have it. In the case of a gift inter vivos, on the other hand, the donor is often still living and may complete an ineffective transfer if he wishes it to be enforced.

3\& Supra note 31 .

35 Supra note 19.

${ }^{86}$ In Moore v. Ulster Banking Co., 11 Ir. C. L. 512 (1877), $M$, shortly before his death, indorsed a bank deposit receipt and delivered it to $S$, stating that it was for $K$. After $M$ 's death $S$ presented the document to the bank, which transferred the amount to $S$. In an action by the administratrix of $M$ against the bank, Edwards v. Jones was affirmed and it was held: (1) that the transaction did not amount to a gift causa mortis; (2) that the deposit-receipt was not a negotiable instrument passing by delivery and indorsement; that the transaction did not constitute an equitable assignment.

In the case of In re Griffin, [1899] 1 Ch. 408 (1898), a father indorsed a deposit receipt "Pay my son," signed his name, and delivered the receipt to his son as a gift inter vivos. The court held there was a good equitable assignment of the deposit. The indorsement amounted to an order or direction to pay which distinguished the case from Moore v. Ulster
} 
Even before Edwards $v$. Jones had determined that choses in action could not pass inter vivos by delivery, the courts were attempting to work out a theory of gifts causa mortis upon which the result in Ward $v$. Tumer could be sustained under the new rules of law which had rendered Lord Hardwicke's reasoning obsolete. In Duffield $v$. Elwes, the donor had attempted to make a gift causa mortis of a bond and the mortgage securing it by delivering the documents to the donee. The Vice-Chancellor held ${ }^{37}$ that the transfer of the written instruments did not complete the gift, for the mortgagor had a right to resist payment of the bond without a reconveyance of the estate and the donor of the bond could not be compelled to complete his gift by such reconveyance. The Vice-Chancellor made it clear that he would not depart from the rule of $W a r d v$. Turner ${ }^{38}$ requiring an effective delivery to complete a gift causa mortis. ${ }^{30}$

On appeal the case came before Lord Eldon, ${ }^{40}$ who reversed the decision of the lower court and held that a trust was raised by operation of law making the donor's executor trustee for the donee. The elements of a trust were lacking;" 12 but the eminent

Banking Co., and the court stated that if anything more was needed to complete the gift, the appointment of the donee as executor for the donor perfected the gift. See also, In re Pryce, $4 \mathrm{Ch} . \mathrm{D}$. 685 (1877), where it was held that an assignment of a debenture of a joint-stocl company by indorsement in blank conferred good title on the assignee as against the trustee in bankruptcy of the assignor.

The gift of a chose by written assignment seems to stand upon a different footing. Such assignments are generally held to be complete and irrevocable. Fortescue v. Barnett, 3 Mryl. \& K. 36 (1834); In re Patrick, [1891] $1 \mathrm{Ch} .82$. In Lee v. MIagrath, L. R. $10 \mathrm{Ir} .313$ (1882), a non-negotiable promissory note was indorsed as follows: "I indorse the within promissory note for $£ 100$ to $\mathrm{my}$ sister L." The note was delivered to $L$ as a gift and the payee died before it fell due. The assignment was held good and Moore v. Ulster Banking Co. distinguished on the ground that there had been no written assignment there but the donor had merely written his name on the deposit receipt.

For interesting discussions of gratuitious assignments in English Lav, see Jenks, op. cit. supra note 1; Anson, op. cit. supra note 1.

371 Sim. \& Stu. 239 (1823).

38 Supra note 19.

89 "Where delivery will not execute .8 complete gift inter vivos, it cannot create a donatio mortis causa, because it will not prevent the property from vesting in the executors; and, as a Court of Equity will not, inter vivos, compel a party to complete his girt, so it will not compel the executor to complete the gift of his testator." Duffield v. Elwes, supra note 37, at 245.

so Supra note 24.

41 This is clear, for the donor never made a declaration of trust and there vas no fraud upon which a constructive trust could be based. This fact has been recognized by later cases which have declared this trust doctrine to be entirely anomalous and limited to gifts cause mortis. In the case of In re Dillon, $44 \mathrm{Ch}$. D. 76, 82 (1890), the court said in referring to. Duffield $\nabla$. Elwes: ". . . the House of Lords there laid it down that the executors were trustees for the donee and must do what was necessary to. 
judge recognized ${ }^{42}$ the changes which had taken place in the law since Lord Hardwicke's time and evidently felt that the transfer of a bond and mortgage could not constitute an effective delivery upon which an equitable assignment might be based. Not being willing to hold that delivery in the old sense of transfer of control was no longer necessary in gratuitous assignments of choses in action, he was compelled to sustain the gift upon some other theory not requiring delivery and the trust doctrine was the only one available. ${ }^{43}$ This decision of Lord Eldon established the trust theory of gifts causa mortis and also determined that mortgages might be the subjects of such gifts.44

It was not until 1851 that the court in Moore v. Darton 4 squarely faced the problem of formulating a theory of delivery which should take the place of that developed by Lord Hardwicke. The important facts of the case were that Miss Darton transferred certain money to Moore and took the following receipt: "Received the 22nd of October 1843, of Miss Darton, five hundred pounds, to bear interest at 4 per cent. per annum, but not to be withdrawn at less than six months' notice. William Moore." 16 Shortly before her death Miss Darton gave this receipt to a servant for Moore intending to make a gift causa mortis to him of the money evidenced thereby. In the administration of Miss Darton's estate it was held that the gift was valid. The Vice-Chancellor made a labored attempt to apply the old rule of Ward $v$. Turner ${ }^{47}$ by which the writing delivered must be one the existence of which is essential to the enforcement of the chose. In speaking of the receipt he said:

perfect the transfer. This would not be so in the case of an incomplete voluntary gift inter vivos-the Court would not interfere to compel either the donor or his executors to perfect it; the doctrine is an anomalous one peculiar to the case of a donatio mortis causa, but it is established by the decision of the House of Lords." The trust doctrine was applied in Cassidy v. Belfast Banking Co., L. R. 22 Ir. 68 (1887).

12 See quotation supra note 24.

$\$ 8$ It is a well known principle of trusts established by Ex parte Pye, 18 Ves. 140 (1811), that one may create himself or his representative trustee for another without consideration and without delivery or transfer of property. But it is necessary that the trustor should declare his intention of creating a trust.

44 Two earlier cases had dealt with the question of gifts of mortgages. In Richards v. Syms, B. \& C. 90 (1740), Lord Hardwicke ordered a retrial on the ground that proof of the delivery of the bond and mortgage to the mortgagor with intent to discharge the debt would extinguish both the debt and the mortgage. The report of Hurst v. Beach, 5 Madd. 351 (1820) is very unsatisfactory but it appears that the Vice-Chancellor believed that the delivery of a bond and mortgage deeds to the debtor would be a good gift causa mortis.

154 De G. \& S. 517 (1851).

46. Another receipt for a hundred pounds was given but it involved a question of trusts which is not pertinent to this discussion.

17 Supra note 19. 
"It was a document contemporaneous, I take it, with the creation of the debt. Now this is the document which was delivered to the agent of the debtor himself. The debt was a debt carrying interest. A mere debt of $\$ 500$ would have arisen from a loan without any writing. But it would not have been a debt carrying interest, without a contract to that effect beyond the advance. That particular contract, I agree, might have been entered into without writing; but as it was created by writing, proof of the writing, if possible, was essential to recovery upon the contract; and it is this writing which was in substance delivered mortis causa to the person owing the money." 48 .

The argument of the court apparently is that a witing creating a contract or embodying its terms " is "in a sense essential" to the proof of the contract for, under the best evidence rule, such a writing, unless its absence was satisfactorily accounted for, would be the only competent evidence of the provisions of the contract. Under this doctrine any chose in action completely evidenced by a written instrument could be made the subject of a gift causa mortis by the delivery of the writing and this appears to be the principle for which M00\%c $v$. Darton is cited and followed. ${ }^{50}$

Shortly after the decision in Moore v. Darton the Master of the Rolls was called upon to decide whether an unindorsed promis-

48 Moore v. Darton, supra note 45 , at 520.

It is interesting to note that the debtor was the donee and that the result of the decision was to release the debtor by surrender of a simple writing without consideration or a written discharge, a rather significant result in view of the statement generally made that the surrender of a simple contract cannot operate as a release. $C f$. Attorney General v. Supreme Council A. L. H., 206 Mass. 183, 92 N. E. 147 (1910).

19 It should make no difference whether the contract were created by a written instrument or was later reduced to writing; for the document is as essential to the proof of the contract in the one case as in the other.

50 In re Dillon, supra note 41 , at 81 , holding a banker's deposit note a good subject of gift causa mortis, contains the following reference to Moore v. Darton: "The mere fact of the deposit rould create a debt; but the document beside acknowledging the receipt of the money, expressed the terms on which it was held, and showed what the contract between the parties was." The deposit note was held to satisfy this test.

The court in Duckworth v. Lee, [1899] 1 Ir. R. 405, 408, referring to the receipt in Moore v. Darton, said: "This receipt was therefore evidence of the entire debt and of all the terms of the loan; it proved als the terms of the contract; and, as the contract was created by writing, proof of the writing was essential to recovery upon the contract." It was. held that an I. O. U. did not satisfy this test.

The following language appears in In re Weston, [1902] $1 \mathrm{Ch} .680,685$ : "... the test appears to be whether or not the document, besides aclonowledging the receipt of the money, expresses the terms on which it is held, and shows what the contract between the parties is." A post office savings bank deposit book was held to come within this rule becouse it contained the essential provisions of the contract. 
sory note payable to order might be the subject of a gift causa mortis, and it was held in Veal v. Veal ${ }^{51}$ that the gift was valid. After reviewing the cases, including Ward $v$. Turner ${ }^{52}$ and Duffield v. Elwes, ${ }^{53}$ the Master recognized the law to be in an unsatisfactory state and rested his decision upon a then unreported case, ${ }^{54}$ decided by Sir John Leach, whose decision in Duffield $v$. Elwes had been overruled by Lord Eldon. ${ }^{55}$ The rule in Moore $v$. Darton is the logical basis for holding that a gift of a promissory note may be made by delivery, but the courts have never explained the theory of their decisions on this subject. Veal v. Veal has been affirmed several times, but without discussion of principle. ${ }^{58}$

Deposit notes or certificates and bank books have been among the most common subjects of gifts and it is the American cases dealing with gifts of these instruments which the framers of the Restatement cite to sustain their interpretation of the law. In view of this fact it is particularly interesting to note the theory of the first English cases ${ }^{57}$ dealing with such gifts. In $M^{\prime}$ Gonnell v. Murray ${ }^{58}$ decided by the Irish Court of Chancery in 1869 , the donor had delivered to the donee a deposit book in a savings bank, attempting to make a gift causa mortis of the deposit. After reviewing the cases from Snellgrove v. Baily ${ }^{50}$ and Ward $v$. Turner ${ }^{10}$ to Moore v. Darton ${ }^{61}$ and Veal v. Veal, ${ }^{02}$ the Master of the Rolls continues:

5127 Beav. 303 (1859).

52 Supra note 19.

53 Supra note 24.

54 Rankin v. Weguelin, 27 Beav. 309 (1829). Bills of exchange payable to order were held proper subjects of a gift cansa mortis. It does not appear whether the bills were indorsed or not and the decision is a mere memorandum citing no authorities and giving no grounds.

55 The Master placed great emphasis upon this fact, arguing that since Sir John Leach had been overruled by Lord Eldon his later decision must have been rendered in conformity with Lord Eldon's opinion, a rather slender argument upon which to base an important decision like that in Veal v. Veal.

56 In re Mead, 15 Ch. D. 651 (1880) (bills of exchange unindorsed); Clement v. Cheesman, 27 Ch. D. 631 (1884) (unindorsed check payablo to order). As to I. O. U., see supra note 53.

Early cases held that an unindorsed note or bill would not pass by delivery. Miller v. Miller, 3 P. Wms. 356 (1735); Tate v. Hilbert, 2 Ves. 111 (1793).

57 Amis v. Witt, 33 Beav. 619 (1863) is the first case holding that a banker's deposit note may pass by gift causa mortis. The decision contains no discussion of principle and is unsatisfactory.

583 Ir. R. Eq. 460 (1869).

so Supra note 17.

oo Supra note 19.

61 Supra note 45.

62 Supra note 51. 
"Assuming these cases to have been all well decided, none of them warrant the proposition contended for before me. To extend the doctrine to a bank-book would be going very much further. I do not find in the acts ${ }^{63}$ relating to Savings Banks anything to distinguish a Savings Bank pass-book from an ordinary banker's pass-book; and were I to decide that the book in this case is a proper subject of a donatio mortis causa, I do not see how I could stop short of holding not only that a bank-book but that any pass-book might be made the subject of such a gift. . $^{4}$ The book of this Savings Bank is rather more unfavorable to the claimant's case than a common bank-book would be; for by the rules printed in it, it appears that payment will be made only to the depositor himself, or on his power of attorney during his life; and after his death smaller sums are payable as specified by the rules; but if the deposit exceeds $\$ 50$, it can only be paid on production of probate or letters of administration; the book is required to be produced, and checked with the bank ledger, and the bank is protected against personation if it be lost. But the book does not embody the terms of the contract between the depositor and the Bank; the only entries to be found in it are figures or sums of money written in full, in a column for that purpose, to prevent fraud. Consistently with the theory that an actual and not a merely symbolical delivery is required, handing over a written contract must be a delivery of the thing given; and the right to assistance in enforcing payment of the money due on it follows. A contract embodied in a writing is in a sense capable of being given; only one person can have it. But it would be going beyond any case yet decided to hold that what is merely evidence of, or a voucher for, the debt-of which there may be several-is capable of being thus dealt with." $\mathrm{cs}$

The test applied was the one laid down in Hoore v. Darton."0 The Master noted that the book under litigation was required to be presented and checked with the bank ledger, but in spite of this fact he held that it was not the proper subject of a gift because it "did not embody the terms of the contract between the

6326 \& 27 VIcT. c. 87, § 6 (3) (1863); 13 CHITtY's ENGLISI STATUTES (6th ed. 1913) 54: "That the depositor's pass-book shall be compared vith the ledger on every transaction of repayment, and on its first production at the bank, after each 20th day of November." "The rules of every savings bank in Ireland shall specify a number of days, not less than two in every year ending on the 20th of November, in which the book of each depositor shall be produced at the office of said savings banle for the purpose of being inspected, examined, and verified with the books of the savings bank by the auditor or auditors." Ibid. 69 .

6s Since the statutes, supra note 63 , required that a depositor's pass-book should be presented at the bank on every transaction of repayment, the later bank book cases would sustain the Master in holding that even a pass-book would be a good subject of gift. But at the time the decision in II'Gonnell v. Murray was rendered the distinction between writings required to be presented to the obligor as a condition to enforcing the contract and those not required to be so presented had not yet been rorlied out.

65 MI'Gonnell v. Mirray, supra note 58.

${ }^{66}$ Supra note 45. 
depositor and the bank" but contained only a column of figures. This reasoning is approved in later cases dealing with deposit notes as ${ }^{67}$ well as bank books. ${ }^{68}$ These cases show that at first certain books were held improper subjects because they did not embody the terms of the depositor's contract, and only later did the courts come to recognize the additional argument of whether or not the book was required to be presented at the bank at the time withdrawals were made. ${ }^{.9}$

Upon the question of the validity of gifts of stock by delivery of the certificate unindorsed and without transfer on the books of the corporation there is practically no conflict in the English authorities. The leading case of Moore v. Moore, ${ }^{70}$ decided in 1874, held that corporation stock could not be made the subject of a gift causa mortis, and it has been regularly followed ever since. ${ }^{71}$ The Vice-Chancellor expressed the basis of his decision as follows:

". . . I said in the course of the argument that I should hold that such stock is not the subject of a domatio mortis causa

or In re Taylor, 56 L. J. 597 (1887); In re Farman, 57 L. J. 637 (1887); Cassidy v. Belfast Banking Co., supra note 41 , at 73 (where the court said of the deposit receipt: "It was a document contemporaneous with the debt, which was delivered to the creditor, and which was essential to the proof of the contract-although the contract was one which might have been entered into without writing"); In re Dillon, supra note 41 (cases roviewed and Moore v. Darton followed); Porter v. Walsh, [1895] 1 Ir. R. 284; Cain v. Moon, [1896] 2 Q. B. 283.

An I. O. U. is not the proper subject of a gift causa mortis. "It did not even state the entire debt; for it is admitted that the debtor agreed to pay, and actually did pay, some interest on the loan; but the I $O U$ was wholly silent as to this. The document handed over was therefore, at best, but imperfect evidence of the debt in respect of which it was given, and which the respondent contends passed by its delivery. It has never been held that the delivery of a document which evidenced part of a simple contract constituted a valid donatio mortis causa of the debt." Duckworth v. Lee, supra note 50, at 407 . In the ordinary case it would seem diffcult to distinguish between an I. $O$. U. and a non-negotiable promissory note.

88 "But the difference between a deposit note, which was the document delivered over in the case of Amis v. Witt, and a pass-book is enormous. A pass-book is not in any degree in the nature of a bond or an agreemont." In re Beak's Estate, L. R. 13 Eq. 489, 491 (1872).

${ }^{69}$ The first reference to this argument appears in Cassidy v. Belfast Banking Co., supra note 41 . In In re Weston, supra note 50, a post office savings bank deposit book was held a good subject of gift causa mortis on the ground that it contained the terms of the contract and also because it was required to be presented at the time withdrawals were made. This is a revival in modernized form of the doctrine of Ward v. Turner. Presentation required by the terms of the contract is substituted for prosentation in court required by the rule of profert.

to L. R. 18 Eq. 474 (1874).

${ }^{71}$ In re Weston, supra note 50; In re Andrews, [1902] 2 Ch. 394; cf. In re Lee, [1918] $2 \mathrm{Ch}$. 320. But of. Searle v. Law, 15 Sim. 95 (1846); McCulloch v. Bland, 2 Giff. 428 (1860). 
at all, and I found this my judgment upon the case of Ward $v$. Turner, before Lord Hardwicke, which I think applicable to the case, holding as I do, notwithstanding that modern cases have gone very far beyond the earlier cases as to donations mortis causa, that the law, if it is to be further extended, must be so extended by a higher tribunal. I consider that stock of this description is not substantially distinguishable from South Sea Annuities." 72

The learned court appears to have misinterpreted Ward v. Turner, ${ }^{73}$ for the thing delivered there was not the annuities but the receipts for them and it was upon this ground that Lord Hardwicke rested his decision. However this may be, the courts have not seen fit to extend the law of gifts to include stock; and Moore $v$ : Moore remains the law in England.

This review of the English cases shows that the English law of gifts is in considerable confusion. The courts have developed and somewhat haphazardly applied several different theories. (1) It has generally been held that an irrevocable gift inter vivos of a chose in action cannot be made, for it is incapable of complete delivery. (2) Gifts causa mortis have been sustained as trusts, or (3) they have been held good equitable assignments where the document delivered embodied the terms of the contract. (4) Lastly, the theory of Ward. $v$. Turner lingers in some of the cases holding that a delivery of a simple writing is not sufficient to complete a gift causa mortis."

The American courts had the advantage of the discussion contained in the early English cases and without difficulty or conflict proceeded to hold, in the first part of the eighteenth century,

72 Mioore v. Moore, supra note 70 , at 483 .

73 Supra note 19.

14 Ward v. Turner was reaffirmed as late as 1927 by the High Court of Justice in the Irish Free State. In the case before the court certain receipts were issued to the donor by the Bank of England and tho Bants of Ireland acknowledged the receipt of the consideration for certain stocls which was to be transferred to the donor. These receipts were delivered with a declaration of gift causa mortis to the donee who claimed the right to the stock. As pointed out by the court, the receipts were not given for the stock but for the consideration paid for the stocis. Mr. Justice Mleredith held the gift incomplete, relying on Ward v. Turner, which he declared to be still the law. He refused to hold that the gift could be completed by way of a trust, although he admitted that the doctrine that equity rill not assist a volunteer by executing an incomplete gift does not apply to gifts causa mortis. In order to raise a trust, he said, ". . . there must in the first instance be something which merely requires to be completed in order to perfect the legal title." In re II'Wey, [1928] Ir. R. 486, 492. In other words the same lind of a delivery will be required to raise a trust as to create an equitable assignment. The case cannot be reconciled with Moore $\nabla$. Darton and illustrates the confusion existing in the English lavi. 
that bonds, ${ }^{75}$ unindorsed bills and promissory notes, ${ }^{70}$ certificates of deposit ${ }^{77}$ and savings bank books, ${ }^{78}$ were all proper subjects of gifts inter vivos or causa mortis. Although gifts of insurance policies by delivery had received little attention in the English cases, ${ }^{79}$ the courts of this country early declared such gifts to be valid. A policy of insurance is a chose in action, a contractual obligation to pay money at a time in the future like a note or a bond and, therefore, the judges saw no reason for distinguishing between insurance policies and the other instruments which had been held proper subjects of gifts without written assignment. ${ }^{80}$

75 Brunson v. Brunson, Meigs 630 (Tenn. 1838); Kiff v. Weaver, 24 N. C. 274 (1886); Wells v. Tucker, 3 Binn. 366 (Pa. 1811).

${ }^{76}$ Brown v. Brown, 18 Conn. 410 (1847); Borneman v. Sidlinger, 15 Me. 429 (1839) ; Kiff v. Weaver, 94 N. C. 274 (1886); Farrell v. Passaic Water Co., 82 N. J. Eq. 97, 88 Atl. 627 (1913); Hopkins v. Manchester, 16 R. I. 663, 19 Atl. 243 (1889); Brunson v. Brunson, supra note 75; 2 KENT, CoMMENTARIES ON AMERICAN LAW (10th ed. 1860) 603.

"It is true that the cases, which are numerous, in which such equitablo assignments have been supported, are founded on assignments for a valuable consideration; but there is little, if any, distinction in this respect, between contracts and gifts inter vivos; the latter indeed, when mado perfect by delivery of the things given, are executed contracts. By dclivery and acceptance the title passes, the gift becomes perfect, and is irrevocable. There is, therefore, no good reason why property thus acquired should not be protected as fully and effectually as property acquired by purchase." Grover v. Grover, 24 Pick. 261, 263 (Mass. 1837).

"Notwithstanding the attempts which have been made in England to distinguish between a promissory note and a bond, in relation to the validity of the gift of a chose in action, there cannot in reason be any difference. A gift of either is valid as a symbolical delivery of the debt due on the note or bond, and all the delivery of which the subject is capable." Coutant v. Scheiyler, 1 Paige Ch. 315, 318 (N. Y. 1829).

77 Mellor v. Bank of Willows, 173 Cal. 454, 160 Pac. 567 (1916); Conner v. Root, 11 Colo. 183, 17 Pac. 773 (1888); Rosenau v. Merchants' Nat. Bank, 56 N. D. 123,216 N. W. 335 (1927); Westerlo v. De Witt, 36 N. Y. 340 (1867). Other cases are collected in Note (1926) 40 A. L. R. 508.

78 Camp's Appeal, 36 Conn. 88 (1869); Ridden v. Thrall, 125 N. Y. 572

(1891). For additional cases see Note (1926) 40 A. L. K. 1249. Postal savings certificates are also a proper subject for gift. Williams v. Letton, $228 \mathrm{Ky} .371,15$ S. W. (2d) 296 (1929).

79 The only English case seems to be Amis v. Witt, supra note 57, where it was held that a gift causa mortis of insurance may be made by delivery of the policy, and that the donee is entitled to the insurance money.

${ }^{80}$ Gordon v. Clark, 149 Ark. 173, 232 S. W. 19 (1921); Chapman v. MicIlwrath, 77 Mo. 38, 45 (1882); McGlynn v. Curry, 82 App. Div. 431, 81 N. Y. Supp. 855 (1903). For other cases see Note (1927) 47 A. L. R. 738; Ann. Cas. 1914D 297; Note (1890) 9 L. R. A. 660.

In Georgia the court has interpreted the code to require assignments of choses in action arising upon contract to be in writing. GA. ANN. CoDE (Michie, 1926) § 3653; Turk v. Cook, 63 Ga. 681 (1879). Applying this rule to insurance policies, it held that delivery without written assignment is not sufficient to constitute a completed gift. Steele v. Gatlin, 115 Ga. 929, 42 S. E. 253 (1902). 
In dealing with these problems the American courts were merely traversing the trails already cut by their English predecessors. ${ }^{8 x}$ Such being the case the decisions contain very little discussion of theory and their reasoning on the question of delivery usually amounts to little more than a repetition of the old cliche that transfer of dominion amounts to a good delivery. But the American authorities have been clear in their repudiation of some of the English views. The courts have refused to recognize any distinction in the requirements of delivery between gifts inter vivos and gifts causa mortis..2 Gifts of the first class have been as readily sustained as those of the second. The rejection of Lord Eldon's trust theory has been equally complete. ${ }^{33}$ A trust will not be raised to execute an incomplete gift whether it be inter vivos or causa mortis. Having reached this result, the courts have seen no inconsistency in continuing to give lip service to the rule that the gift of a chose in action requires complete delivery to execute it, while at the same time they have been sustaining gifts which the English courts have declared invalid for want of delivery, ${ }^{86}$ or have held valid only

81 In cases of gift of shares of stock the American courts have talsen a more liberal view than the English judges. The majority view is that a gift of stock may be made by delivery of the certificate unindoreed and without transfer on the books of the corporation. Allerton v. Lang, 10 Bosw. 362 (N. Y. 1863); Walsh v. Sexton, 55 Barb. 251 (N. Y. 1869); Orton v. Tannenbaum, 194 App. Div. 214, 185 N. Y. Supp. 681 (2d Dep't 1920), commented upon in (1920) 30 YaLe I. J. 767; Stone v. Hackett, 12 Gray 227 (Mass. 1858) ; Herbert v. Simson, 220 Mass. 480, 108 N. E. 65 (1915); Leyson v. Davis, 17 Miont. 220, 263, 42 Pac. 775 (1895). Contra: Matthews v. Hoagland, 48 N. J. Eq. 455, 21 Atl. 1054 (1891). See Mechem, Gifts of Corporation Shares (1925) 20 ILr. L. REv. 9.

- 82 Camp's Appeal, supra note 78, held that a savings bank bools was a good-subject of a gift inter vivos. Referring to an earlier case, the court said: "It is true that was a donatio causa mortio; but the principle involved is the same in both cases, as there is no difference in respect to the requisites of a delivery between the two classes of gifts." Ibid 93. In Hopkins จ. Manchester, supra note 76, the lower court held that an unindorsed promissory note would pass causz mortis but not inter vivos. The upper court reversed the decision saying: "We do not find that the cases distinguish in this respect between gifts inter vivos and gifts causa mortis." Ibid. 664. The rule of these cases may be contrasted with the English view expressed in Moore v. Ulster Banling Co., oupro note 36 , where it was held that a deposit receipt could not pass by gift inter vivos.

8312 R. C. L. 951 and cases there cited. An occasional indication to the contrary may be found, as in Grymes v. Hone, 49 N. Y. 17, 22 (1872), where the court stated: "The representatives of the donor were trustees for the donee by operation of law to make the gift effectual. This trust, like this species of gift, is peculiar. . . . This extended the larr as laid down by Lord Hardwicke in Ward $\nabla$. Turner upon this subject, and our courts have gone in the same direction with Duffeld v. Elves."

8s Supra note 36. 
on the trust theory. ${ }^{85}$ In view of this situation, what has the requirement of delivery in gifts of choses in action come to mean? Whatever the courts may say, their decisions compel one to accept the view that it means nothing more than the transfer of an instrument which is the complete and best evidence of the obligation assigned.

This conclusion is most strikingly illustrated by the American cases dealing with gifts completed by the transfer of receipts or similar instruments. The earliest case of this kind is Elam $v$. Keen, ${ }^{86}$ decided by the Supreme Court of Virginia in 1833. A owned a bond which he had deposited with his attorney who had given him a receipt. $A$ delivered this receipt to $B$ with a proper declaration of gift. The court held the gift valid, declaring that $B$ could recover the money collected on the bond by the attorney as against the executor of $A$. The opinion mentions Ward $v$. Turner but proceeds on the theory that there was a good symbolical delivery comparable to the delivery of a key. The terms of the receipt are not set forth in the report but the court does not intimate that it was required to be presented to the attorney at the time the return of the bonds was requested.

A very interesting Kentucky case is that of Stephenson's $A d m^{\prime} r v$. King. ${ }^{g r}$ Here the donor selected the defendant as her agent for the management of her business affairs and placed certain money in his hands for investment. Sometime before the transaction in controversy she wrote to the defendant inquiring about the condition of her accounts and, in the words of the court, he responded "on the 13th of April, 1880, in which he says: 'I now have in my safe one promissory note belonging to you on W. P. Hahn and Mattie Hahn, dated February 13th, 1878; payable five years after date, for $\$ 5,500$, with interest from maturity at eight per cent. per annum' and also recites the $\$ 500$ Taylor county bonds, etc." ${ }^{88}$ This letter was signed by the defendant, and was delivered by the donor to the donee as a gift causa mortis of the securities held by the defendant. In an action brought by the administrator of the donor against the defendant it was held that the gift was valid and that the securities belonged to the donee. In speaking of the transfer of the letter the court made the following statement:

"No other delivery could have been made, and the arbitrary rule such as formerly existed with reference to the delivery of choses in action, requiring an assignment and delivery of the. identical thing in order to make such a gift valid, having long since been abandoned, there is no reason why the intention to

\footnotetext{
85 Supra note 41.

864 Leigh 333 (Va. 1833).

8781 Ky. 425 (1883).

83 Ibid. 428.
} 
give, with the actual delivery of the written evidence of the right to the thing, although in the possession of another, under the belief of the donor that it perfects the gift, should not be held to constitute a valid gift causa mortis." "s

A comparatively recent case is Kaufmann v. Parmele, ${ }^{00}$ decided by the Supreme Court of Nebraska in 1916. There, one Volk was the holder of the following receipt:

"Received of William Volk, for safe-keeping, $\$ 10,000$ six per per cent. gold coupon bonds; $\$ 5,000$ six per cent. preferred stock, Long Distance Telephone Company of Norfolk, Nebraska. It is agreed between Thomas E. Parmele and William Volk that these bonds and stock are to be held at the Bank of Commerce, at Louisville, Nebraska, for five years, and the income to be paid over to William Volk as paid. Thomas E. Parmele."

Shortly before his death Volk delivered this receipt to the plaintiff as a gift. After Volk's death the plaintiff sued Parmele for the conversion of the securities and the court held the gift valid. The following interesting statement appears in the opinion:

"The receipt was a symbol of ownership. It was written evidence of defendant's obligation to keep the property for Volk and to return it to him or to his assign. It was all Volk had in his possession to deliver when he made his donation. ... Plaintiff acquired the rights of Volk, and with those rights defendant is not in a position to interfere. Plaintiff's ownership by gift is therefore established by uncontradicted evidence."

This line of of cases ${ }^{2}$ establishes the rule that the delivery of a receipt evidencing the obligation of a third party to return property or to repay money may operate as a gift of the prop-

\footnotetext{
89 Ibid. 435 .

3099 Neb. 622,157 N. W. 342 (1916).

91 Ibid. 624, $157 \mathrm{~N}$. W. at 342 .

${ }^{2}$ Lipson v. Evans, 133 Md. 370, 105 Atl. 312 (1918); Goldsworthy v. Johnson, 45 Nev. 355, 204 Pac. 505 (1922). In these cases an indorsement and written assignment appeared on the back of the receipts but the courts lay no emphasis on this fact. In both cases the deliverg was held to be symbolical and Ward v. Turner was referred to.

In Champney v. Blanchard, $39 \mathrm{~N}$. Y. 111 (1868), the following receipt was delivered to the debtor: "Receired, Brooklyn, Mray 21st, 1863, from J. Hegeman, $\$ 2803.50$, also, June 1st $\$ 500.00$ from A. S. Foster, both of which sums are on account of and belonging to Mrs. Mary Chempney, and are to be disposed of in any manner she may direct, as paid to her individually, together with whatever interest I may obtsin for their use. F. Blanchard." The court held that the transaction between Mrs. Champney and Blanchard created a deposit and that the delivery of the receipt constituted a gift thereof. As in Mloore v. Darton, supro note 45 , tho debtor in the case was the donee. In Claytor ₹. Pierson, 55 W. Va. 167, 46 S. E. 935 (1904), the receipt read: "Serrell, W. Va., August 26th 1899. \$1100. Eleven hundred dollars. Received of William Claytor for safelseeping. L. C. Claytor." The transfer of this receipt was held to complete a gift of the deposit.
} 
erty or the deposit. Whether the terms of the transaction require the return or presentment of the receipt to the obligor is entirely immaterial and the courts nowhere refer to such a requirement as being important. The delivery of the receipt is sufficient to complete the gift because it is complete evidence of the obligation assigned. The receipt cases are therefore opposed to the rule of the Restatement.

Even in the case of gift by delivery of a written contract, referred to at the beginning of this paper, the American courts have held the assignment valid and irrevocable, contrary to the view expressed in the Restatement. In the Pennsylvania case of In re Huggin's Estate, ${ }^{03} A$ agreed to convey certain coal rights to $B$ for $\$ 1,800$, the money to be paid before the execution of the deed. The agreement was put into writing and $A$, desiring to make a gift of the $\$ 1,800$, delivered the writing to $C$. $A$ died, and the question arose as to whether $A$ 's executors were entitled to the $\$ 1,800$. The court held that they were not, for the gift was complete and $C$ had the right to the money. ${ }^{04}$

The authors of the Restatement admit that In re Huggin's Estate is contra to their statement of the law of assignment, but they evidently regard it as standing alone. In commenting upon the case they state:

"It should be observed, however, that the Pennsylvania court has repeatedly laid down in recent cases the principle that 'to establish a gift inter vivos, two essential elements must be made to appear; an intention to make the donation then and there,

93 Supra note 6.

94 The fact that the deed was yet to be executel and that the title was still in the representatives of $A$ was immaterial, for the execution of tho deed was not a condition precedent to the payment of the money. It was decreed that the deed should be executed by $A$ 's executors and delivered to $C$ in escrow.

95 Two other cases are cited as being in conflict with the theory of the Restatement. One is Jones, Adm'r v. Moore, $102 \mathrm{Ky} .591,44 \mathrm{~S}$. W. 126 (1898), where it was held that the delivery of a book of accounts coupled with gift intent created an irrevocable gift of the accounts of which the book was evidence. The other is Murphy v. Bordwell, 83 Minn. 54, 85 N. W. 915 (1901), in which the facts were as follows: $A$, wishing to make a gift of a bank account to $B$, instructed the cashier to make out the proper papers. The latter drew a power of attorney to himself which $A$ signed, and the cashier then gave $B$ a check book. $B$ withdrow sums from time to time by bringing the check book to the bank and instructing the cashier to make out the checks which he did. A creditor of $A$ attempted to garnishee the account but it was held that he could not, for the gift to $B$ was complete. Why may not the power of attorney be regarded as a written assignment of the account, by which $A$ constituted the cashier the agent of $B$ ? Under this view the case deals with gifts by written assignment and not by delivery. If such be true, it may not be contra to the Restatement, on the theory of Fortescue v. Barnett and othor cases, supra note 36. Contracts Restatement (Am. L. Inst. 1928) c. 1-7, p. 271. 
and an actual or constructive delivery at the same time, of $a$ nature sufficient to divest the giver of all dominion, and invest the recipient therewith." "so

Nothing has been more confusing in the law of gifts than this question-begging and mind-befogging dominion concept by which the authors of the Restatement apparently attempt to discredit the decision of the Pennsylvania court. However useful the idea of transfer of dominion may have been in Lord Hardwicke's time, when it was first applied to gifts of choses in action, it has long outlived that usefulness and certainly furnishes no basis today for holding that the transfer of a written contract cannot operate as an irrevocable gift of the chose represented by the document.

This contention is sustained by the review of the cases given above. There is no logical reason for distinguishing between gifts consummated by the delivery of non-negotiable promissory notes, insurance policies, and receipts, on the one hand, and written contracts on the other. No one of these instruments is any more essential to the enforcement of the chose which it evidences than are the others. Each of them is complete evidence of the obligor's duty as well as the best evidence of the obligee's right and not one of them is necessarily required to be presented to the obligor as a condition of enforcing the obligee's claim against him. In re Huggin's Estate is in accord with the development of the American law ${ }^{\circ r}$ and is sustained by the English cases following the rule of Moora v. Darton.

The cases relating to gifts of bank pass-boolss are cited in the Commentaries to the Restatement as supporting the authors' interpretation of the law; but it is submitted that an analysis of the decisions in these cases will show that they are not in con-

96 Ibid.

${ }^{97}$ A similar case is Davie v. Davie, 47 Wash. 231, 91 Pac. 950 (1907). $A$ contracted to sell certain land to $B$ and the contract was reduced to priting. Upon the payment of the purchase price the deed was to ba delivered to $B$. Desiring to make a gift of the proceeds to $C$, his wife, $A$ delivered the contract and the deed to her. After $A$ 's death the question arose as to the validity of the gift and the court held it valid.

In Estate of Cronan, Myrick 72 (Cal. 1874), $A$ bargained to sell a lot to $B$ for $\$ 1,000$. $A$, being sick, said to $C$, "Get the $\$ 1000$ from $B$, pay sickness and burial expenses and keep the rest." At the same time he gave $C$ a paper, but what it was never appeared at the trial, since $C$ could not read. After $A$ 's death $C$ took the paper to $B$ and excured the money. The court held the gift complete on the theory that $C$ received from $A$ a paper which authorized her to obtain the money from $B$ and this was a suficient delivery.

These cases should be compared with Attorney General v. Supreme Council, A. I. H., 206 Miass. 183, 92 N. E. 147 (1910), where the court held that the surrender of a simple contract could not discharge the obligor. 
flict with the doctrine represented by In re Huggin's Estate. It is held that the transfer of a pass-book is not a sufficient delivery to complete a gift of the deposit. ${ }^{.8}$ The reason usually given is that the book is not required to be presented at the time withdrawals are made and hence its delivery does not transfer control over the deposit. ${ }^{99}$ While this cannot be denied, it is equally true that the ordinary pass-book is not necessarily evidence of any obligation on the part of the bank. It is nothing more than a memorandum ${ }^{100}$ showing that certain deposits have been made but not indicating whether they have been wholly or partially withdrawn and not stating what balance if any is due the depositor. These matters cannot be shown in a book which is not required to be presented when withdrawals are made.

This incomplete character of pass-books has been recognized by the courts. The North Carolina court in distinguishing the delivery of a pass-book from that of a bond made the following statement: “The 'deposit book' is no more than a memorandum, binding no one, containing no obligation, and could only be used to refresh the memories of the depositor and depositee as to dates and amounts of their dealings." ${ }^{101}$ In discussing the rule of Moore v. Darton the Irish court said in M'Gonnell v. Murray: "But the book does not embody the terms of the contract between the depositor and the bank; the only entries to be found in it are figures or sums of money written in full, in a column for that purpose, to prevent fraud." ${ }^{102}$

Since this is the nature of a pass-book, ${ }^{103}$ the cases holding

98 Jones v. Weakley, 99 Ala. 441, 12 So. 420 (1893); Wilson v. Featherston, 122 N. C. 747,30 S. E. 325 (1898); Thomas, Adm'r v. Lewis, 89 Va. 1,15 S. E. 389 (1892). Kentucky does not follow this view. Ashbrook v. Ryon's Adm'r, 2 Bush 228 (Ky. 1867), overruled by McCoy's Adm'r v. MeCoy, $126 \mathrm{Ky} .783,104$ S. W. 1031 (1907).

${ }^{30}$ This is the basis of the distinction between pass-books and savings bank books. See authorities cited supra note 78.

100 The delivery of an incomplete memorandum was considered in the famous case of Cook v. Lum, 55 N. J. L. 373 (1893). G deposited $\$ 2,316$ with $K$, who gave $G$ a piece of paper with eight sums on it which were footed to $\$ 2,316$. The paper was unsigned and contained nothing else but the date. $G$ delivered this paper to $C$ with intent to make a gift of tho deposit. The court held the delivery insufficient. The paper did not $\mathrm{cm}$ body the terms of any obligation and for this reason the decision is sound. See infra notes 103, 104.

As to the gift of an open account by the delivery of a book of accounts, see Jones' Adm'r v. Moore, 102 Ky. 591, 44 S. W. 126 (1898); Ashby v. Carr, 40 Miss. 64 (1866); Cornwell v. Baldwin's Bank, 12 App. Div. 227, 43 N. Y. Supp. 771 (4th Dep't 1896).

101 Wilson $\nabla$. Featherston, supra note 98 , at 751, 30 S. E. at 326.

102 Supra note 58.

103 The fact that a pass-book is not a written obligation is illustrated by Stark v. Long, 270 S. W. 1095 (Tex. Civ. App. 1925), where it was held, 
that the delivery of such a book cannot operate as a gift of the deposit throw no discredit upon the doctrine of In re Huggin's Estate or any other of the cases holding that the delivery of an instrument completely evidencing an obligation ${ }^{104}$ may operate as an irrevocable assignment of the chose.

In light of this discussion the following restatement is suggested as representing the law of gifts of choses in action by delivery:

The right acquired by the assignee under a gratuitous assignment is revocable by the assignor's death, by a subsequent assignment by the assignor, or by notice from the assignor received by the assignee or by the obligor unless: (a) ... ${ }^{\text {ies }}$ or (b) the assignor delivers to the assignee an instrument in writing which satisfies one or both of the following requirements:

(1) that it be an instrument which, by the terms of the as-

that a notation in a bank pass-book is not a contract in writing binding the bank to pay the depositor the amount stated. See also, 1 LIORSE, BANkB AND BANKING (6th ed. 1928) § 290.

In Talcott v. First Nat. Bank of Larned, 53 Kan. 480, 36 Pac. 1066 (1894), it was held that an action on a deposit evidenced by a pass-book is not an action within a statute providing: "An action upon any agreement, contract or promise in writing" must be brought "within five Jears." The case was distinguished from one where the action was brought on a certificate of deposit which the court held to be an action upon a mitten contract. The court in the Talcott case said that a certificate of deposit contains a written promise to pay but a pass-book does not. This case should be carefully distinguished from Schalucky v. Field, 124 Ill. 617, $16 \mathrm{~N}$. E. 904 (1888), holding that an action on a pass-book is within a statute providing, "Actions on bonds, promissory notes, bills of exchange, written leases, written contracts, or other evidences of indebtedness in writing shall be commenced within ten years. ..." A pass-bools is an evidence of indebtedness, so the court said, but it is not a written obligation.

I0s Cases relating to actions upon receipts are very instructive as to what instruments constitute written obligations. As pointed out by the Indiana court, a simple receipt merely acknowledging the payment of money or the delivery of a thing is but prima facie evidence of the fact of payment or delivery and does not exclude parol testimony dealing with the same fact. But if the receipt also contains a contract to do something in relation to the thing delivered, in so far as it is evidence of that contract between the parties, it stands on the footing of all other contracts in writing and cannot be contradicted or varied by parol. Dale v. Evans, 14 Ind. 288 (1860). Thus an instrument reading, "Received of Joseph S. Long sixteen hundred dollars, on deposit, in National currency. Straus Bros." is a written contract for the payment of money within the statute of frauds, for the words "on deposit" import a contract. Long v. Straus, 107 Ind. 94, 6 N. E. 123 (1886). Similarly the phrase, "for safe keeping" implies a promise. Tisloe v. Graeter, 1 Blaclef. 353 (Ind. 1825). And the word "payable" First Nat. Banls of Farmersville $v$. Greenville Nat. Bank, 84 Tex. 40 (1892). An unsigned deposit slip binds no one and hence does not constitute a written obligation. Van Vleet $v$. McCarn, 18 N. Y. St. Rep. 73, 2 N. Y. Supp. 675 (Sup. Ct. 1888).

105 No changes are suggested in (a) or (c) and they are therefore not re-printed. 
signed contract, is required to be presented or surrendered to the obligor as a condition to the obligor's duty to perform; or

(2) that it be an instrument acknowledging and setting forth the terms of the indebtedness or obligation on the part of the obligor; or (c) ....

It is the purpose of clause (1) to state the rule of the savings bank book cases which should be applicable to any instrument required to be presented to the obligor. This suggested subsection involves no substantial change in Section 158 (1) clause (b) as it now stands in the Restatement. The existing section describes the instrument delivered as a "tangible token or writing, the surrender of which is required by the obligor's contract for its enforcement." It is submitted that the suggested subsection is clearer in defining the instrument as one "which, by the terms of the assigned contract, is required to be presented or surrendered to the obligor as a condition to the obligor's duty to perform." This statement leaves no doubt as to the way in which the surrender of the instrument would be required for the enforcement of the contract.

In clause (2) an attempt is made to set forth the principle of the cases dealing with non-negotiable promissory notes, insurance policies, receipts, written contracts, and similar instruments not required to be presented to the obligor. The phrase "acknowledging and setting forth the terms of the indebtedness or obligation on the part of the obligor" implies that the instrument shall contain the obligor's express or implied promise ${ }^{100}$ to perform the assigned contract and implies further that the instrument shall be signed by the obligor or his agent and shall contain the essential provisions of the contract.

The rule that an irrevocable gift of a chose in action may be made by the delivery of an instrument completely evidencing it not only states the view of the authorities, but expresses a sound policy. The chief value of the requirement of delivery is the fact that the act of transferring the property is evidence of the donor's intent and, perhaps what is more important, serves to impress upon the donor the significance of his act. These purposes are served by the delivery of a writing which embodies the obligation assigned. Such an instrument represents the chose, at least to the layman if not to the lawyer, and its delivery impresses upon the donor the significance of his act and fairly indicates his intention to consummate the gift.

${ }^{108}$ The obligor's promise may be implied from a construction of the terms of the instrument. See supra note 104. 